University of Nebraska - Lincoln

DigitalCommons@University of Nebraska - Lincoln

Faculty Publications from the Harold W. Manter Laboratory of Parasitology

6-1963

Arhythmorhynchus capellae sp. n. (Polymorphidae: Acanthocephala), A Parasite of the Common Snipe Capella gallinago delicata

Gerald D. Schmidt

University of Northern Colorado

Follow this and additional works at: https://digitalcommons.unl.edu/parasitologyfacpubs

Part of the Parasitology Commons

Schmidt, Gerald D., "Arhythmorhynchus capellae sp. n. (Polymorphidae: Acanthocephala), A Parasite of the Common Snipe Capella gallinago delicata" (1963). Faculty Publications from the Harold W. Manter Laboratory of Parasitology. 396.

https://digitalcommons.unl.edu/parasitologyfacpubs/396

This Article is brought to you for free and open access by the Parasitology, Harold W. Manter Laboratory of at DigitalCommons@University of Nebraska - Lincoln. It has been accepted for inclusion in Faculty Publications from the Harold W. Manter Laboratory of Parasitology by an authorized administrator of DigitalCommons@University of Nebraska - Lincoln. 


\title{
Arhythmorhynchus capellae sp. n. (Polymorphidae: Acanthocephala), A Parasite of the Common Snipe Capella gallinago delicata*
}

\author{
Gerald D. Schmidt \\ Department of Zoology, Colorado State University, Fort Collins
}

\begin{abstract}
Arhythmorhynchus capellae sp. $\mathrm{n}$. is described. The description is based on seven males and seven females from the Common Snipe in northern Colorado. The species is contrasted with two similar species, A. comptus Van Cleave and Rausch, 1950 and A. eroliae (Yamaguti, 1939) Van Cleave and Rausch, 1950. It differs from the former in having 14 proboscis hooks per row rather than eight or nine, and from the latter in having no bursal rays and 16 rows of 14 hooks rather than 18 rows of 12 to 13 hooks.
\end{abstract}

This species is described from 14 specimens, seven males and seven females, recovered from the small intestines and ceca of six Common Snipe Capella gallinago delicata taken between January 1961 and March 1962 in northeastern Colorado.

All measurements are in microns unless otherwise indicated.

Arhythmorhynchus capellae sp. n.

Description: Bright yellow and wrinkled when removed from gut. Trunk long and narrow with slight inflation at anterior end. Proboscis nearly cylindrical, armed with 16 longitudinal rows of 14 hooks each, 50 long and not appreciably heavier midventrally; the first three and last four hooks in each row more delicate, measuring 42 to 45 long. Neck about 350 long. Body spines extend about $1.74 \mathrm{~mm}$ posterior from neck, less numerous toward rear; length 30 to 35 . Subcuticular nuclei restricted to narrow band at swollen area of trunk.

Male: Length 12 to $41 \mathrm{~mm}$ ( $35 \mathrm{~mm}$ ); diameter at midpoint of body 222 to 666 (494). Proboscis length 610 to 721 (653); width 144 to 200 (166). Armature same in male and female. Two testes contiguous, each about $1.43 \mathrm{~mm}$ long, located 1.10 to $1.30 \mathrm{~mm}$ behind field of body spines. Two tubular cement glands extend from area imme-

Received for publication 17 September 1962.

* Part of a thesis submitted to the Graduate School of Colorado State University in partial fulfillment of the requirements for the degree of Master of Science, March 1962, under the direction of Dr. O. W. Olsen.

This investigaiton was in part supported by a training grant [PHS-2E-94 (cl)] from the Institute of Allergy and Infectious Diseases of the National Institutes of Health, U. S. Public Health Service. diately behind posterior testis and join common sperm duct posterior to Saefftigen's pouch.

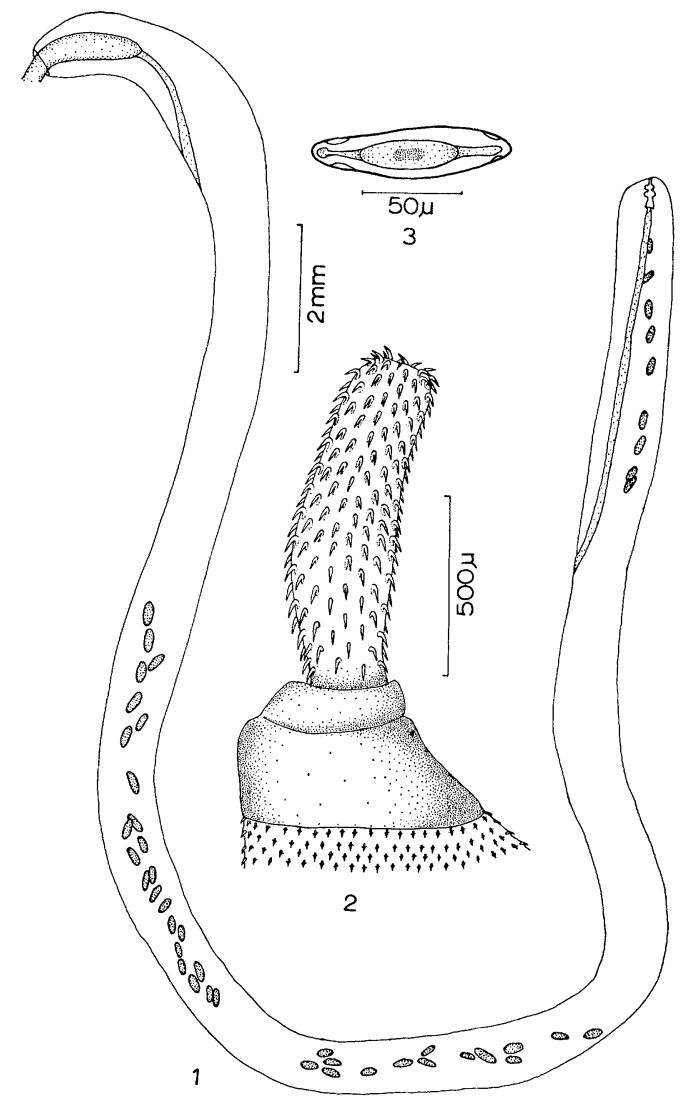

Arhythmorhynchus capellae sp. $\mathrm{n}$.

Figure 1. Allotype female.

Figure 2. Proboscis of paratype male.

Figure 3. Mature egg, observed in pseudocoel of fixed and stained female. 
Female: Length 20 to $50 \mathrm{~mm}$ ( $37 \mathrm{~mm}$ ); diameter at midpoint of body 432 to 666 (548). Proboscis length 666 to 721 (695); diameter 122 to $233(160)$. Suspensory ligament degenerating early; developing eggs and ovarian balls filling pseudocoel. Uterine bell 67 wide at top, tapering to 7 in the center of the first of two large uterine sphincters; length 195. Muscular vagina 80 long by 75 wide. Length from mouth of uterine bell to vaginal opening, 410. Mature eggs 92 to 100 long by 17 to 20 wide, measured in pseudocoel of fixed and stained female worm. Immature eggs with small knob at each end.

Host: Capella gallinago delicata.

Habitat: Small intestine and cecum.

Locality: Northeastern Colorado.

Type specimen: Holotype male, allotype female USNM Helm. Coll. No. 59657.

\section{DISCUSSION}

Of the 21 species of Arythmorhynchus recorded in the literature, only A. comptus Van Cleave and Rausch, 1950 from sandpipers in Alaska and A. eroliae (Yamaguti, 1939) Van Cleave and Rausch, 1950 from sandpipers in Japan are sufficiently similar to the present species to warrant differentiation. The other species differ greatly in size, shape, and arrangement of hooks, shape of proboscis, and internal anatomy.

A. comptus differs from A. capellae in that its proboscis is shorter and spindle-shaped, its body spines are smaller, and its embryo is larger. Also, only eight or nine proboscis hooks are present in each row compared with 14 in A. capellae. A. eroliae possesses 18 rows of 12 to 13 hooks and bursal rays, while $A$. capellae has 16 rows of 14 hooks and no bursal rays. These differences are deemed adequate to justify designating the specimens from Colorado as a new species.

LITERATURE CITED

Van Cleave, H. J., and R. L. Rausch. 1950. A new species of Arhythmorhynchus from sandpipers of Alaska. J. Parasit. 36: 278-283.

YamaguTI, S. 1939. Studies on the helminth fauna of Japan. Part 29. Acanthocephala, II. Jap. J. Zool. 8: 317-351. 